\title{
Contents, Vol. 67, 1995
}

\section{No. 1}

Message from the Editors

The Merger of Developmental Pharmacology and 1 Therapeutics and Biology of the Neonate Aranda, J.V.; Relier, J.P.

Editorial

Update on Surfactant Therap

Report from the 9th International Workshop on

Surfactant Replacement, Jerusalem, May 22-25,

1994

Shinwell, E.S.; Robertson, B.; Saugstad, O.D.;

Halliday, H.L.; Speer, C.P.

Original Paper

Prospective, Randomized, Controlled Evaluation 13 of a Gentamicin Loading Dose in Neonates

Semchuk, Wm,; Shevchuk, Y.M.; Sankaran, K.;

Wallace, S.M.

Middle Cerebral Artery Velocity Waveforms in 21 Fetuses with Absent Umbilical Artery EndDiastolic Flow

Mimica, M.; Pejkovic, L.; Furlan, I.; Vulic-Mladinic, D.; Praprotnik, T.

Neutrophils from Preterm Neonates and Adults 26 Show Similar Cell Surface Receptor

Expression: Analysis Using a Whole Blood Assay Falconer, A.E.; Carr, R.; Edwards, S.W.

The Presence of Prolidase Activity in Amniotic 34 Fluid and Its Evaluation as a Maturity Test

Gürdöl, F.; Genç, S.; Yalçin, Ö.; Gültepe, M.

Perinatal Factors and 2-Year Minor Neuro- 39

developmental Impairment in Low Birth

Weight Infants

Spinillo, A.; Fazzi, E.; Orcesi, S.; Accorsi, P.;

Beccaria, F.; Capuzzo, E.

Gastrointestinal and Pancreatic Hormones in the 47

Human Fetus and Mother at 18-21 Weeks of

Gestation

Adrian, T.E.; Soltesz, G.; MacKenzie, I.Z.; Bloom, S.R.;

Aynsley-Green, A.

Oxygen Saturation in Premature Neonates with 54 Bronchopulmonary Dysplasia in a Hammock Zanardo, V.; Trevisanuto, D.; Dani, C; Bottos, M.; Guglielmi, A.; Cantarutti, F.

Elastase Given Intracisternally Opens Blood59

Brain Barrier in Newborn Piglets Temesvári, P.; Abraham, C.S.; Gellén, J., Jr.; Speer, C.P.; Kovács, J.; Megyeri, P.

Differential Expression of $\alpha$ - and $\beta$-Thyroid 64 
Hormone Receptor Genes in the Developing Rat Brain under Hypothyroidism Chattopadhyay, N.; Kher, R.; Virmani, J.; Godbole, M.M.

Short Communication

Effect of Pentoxifylline on Nitric Oxide Released 72

by Murine Macrophages

Lauterbach, R.; Grabowska, A.; Marcinkiewicz, J.

No. 2

Original Paper

Embryogenesis in vitro: Study of Differentiation 77 of Embryonic Stem Cells

Dushnik-Levinson, M.; Benvenisty, N.

Ketone Body Turnover at Term and in Prema- 84 ture Newborns in the First 2 Weeks after Birth de Boissieu, D.; Rocchiccioli, F.; Kalach, N.; Bougnères, P.F.

Oxygen Saturation during and after Feeding in 94 Healthy Term Infants Hammerman, C;

Kaplan, M.

In vitro Model of Human Umbilical Venous Per- 100 fusion to Study the Effects of Meconium

Staining of the Umbilical Cord Pickens, J.; Toubas, P.L.; Hyde, S.; Altshuler, G.

Lipid A Binding to Neonatal and Adult Red 109

Blood Cells

Pöschl, J.M.B.; Schnauffer, M.; Galanos, C;

Linderkamp, O.

Ill

Ontogeny of Group II Phospholipase A2 Gene 113 Expression in Rat Stomach and Ileum

Dimberg, J.; Lilja, I.; Weström, B.; Tagesson, C; Söderkvist, P.; Gustafson-Svärd, C.

Maternal Dietary Carbohydrate Restriction 122

Influences the Developmental Profile of Postnatal Rat Brain Indoleamine Metabolism Koski,

K.G.; Lanoue, L.; Young, S.N.

Relationship between Associations of NOR and 132 Chromosomal Anomalies in the Abnormal Embryos of Nonobese Diabetic and STZ-Diabetic Mouse

Tatewaki, R.; Hashimoto, R.; Tanigawa, K.; Furuse, K.; Tanaka, O.

Effect of Intrapartum Meperidine on Behavior of 140 3- to 12-Month-Old Infant Rhesus

Monkeys Golub, M.S.; Donald, J.M.

No. 3

Editorial

Amino Acid Oxidation and Urea Production 149

Rates in Fetal Life Battaglia, F.C.

Original Paper

Maternal-Fetal Folate Status and Neural Tube 154 Defects: A Case Control Study Bunduki, V.;

Dommergues, M.; Zittoun, J.; Marquet, J.; Muller, F.; Dumez, Y.

Obstetric Risk Factors Affecting Incidence of 160

Low Birth Weight in Live-Born Infants Abdulrazzaq, Y.M.; Bener, A.; Dawodu, A.; Kappel, I.; Surouri, F.A.; Varady, E.; Liddle, L.; Varghese, M.; Cheema, MY.

Closure of Patent Ductus arteriosus Decreases 167 Pulmonary Myeloperoxidase in Premature Infants with Respiratory Distress Syndrome Varsila, E.; Hallman, M.; Venge, P.; Andersson, S. 172

Early Minimal Feedings Promote Growth in Critically Ill Premature Infants Troche, B.; HarveyWilkes, K.; Engle, W.D.; Nielsen, H.C.; Frantz, I.D., III; Mitchell, M.L.; Hermos, R.J. 
End-Tidal Carbon Monoxide in Newborn

182

Infants: Observations during the 1 st Week

of Life

Balaraman, V.; Pelke, S.; DiMauro, S.; Cheung, S.;

Stevenson, D.K.; Easa, D.

Effect of Hypoinsulinemia on Growth in the 186

Fetal Rabbit

Chaffin, D.G.; Clark, R.M.; McCracken, D.;

Philipps, A.F.

Lack of Production and Growth-Modulating 194

Effects of 1 $\alpha, 25$-Dihydroxyvitamin D3 in Cultured Fetal Rat Hepatocytes Partyka, CM.; Gelardi, N.L.; Fadden, K.; Rifai, A.; Gruppuso, P.A.; Oh, W.; Reddy, G.S.

Acute Entry of Bilirubin into Rat Brain Regions 203 Hansen, T.W.R.

Retinal and Choroidal Blood Flow Response to 208

Hyperoxemia after Severe Hypoxemia in the

Newborn Piglet

Odden, J.-P.; Rootwelt, T.; Stiris, T.; Hall, C;

Bratlid, D.

Does Endothelin-1 Mediate the Hypoxemia- 216

Induced Renal Dysfunction in Newborn

Rabbits?

Semama, D.S.; Thonney, M.; Guignard, J.-P.

Metabolism of Chloramphenicol by Glutathione 230

S-Transferase in Human Fetal and Neonatal

Liver

Holt, D.E.; Hurley, R.; Harvey, D.

Effect of L-Arginine Infusion on Infants with

Persistent Pulmonary Hypertension of the

Newborn

McCaffrey, M.J.; Bose, C.L.; Reiter, P.D.; Stiles, A.D.

IV

Contents

Scanning Gel Densitometry of Amniotic Fluid 244

Acetylcholinesterase and Butyrylcholinesterase:

Quantification of 'Faint-Positive' Bands in Fetal

Malformations

Dupont, M.; Vallet, B.; Brim, A.; Boulot, P.; Demaille, J.

Activities of Trypsin and Lipase in Duodenal 248 Aspirates of Healthy Preterm Infants: Effects of Gestational and Postnatal Age Boehm, G.; Bierbach, U.; DelSanto, A.; Moro, G.; Minoli, I. Intestinal Transport and Processing of Immuno- 254 globulin $\mathrm{G}$ in the Neonatal and Adult Rat Benlounes, N.; Chedid, R.; Thuillier, F.; Desjeux, J.F.; Rousselet, F.; Heyman, M.

Effect of Retinoids on Fetal Lung Development 264

in the Rat

Masuyama, H.; Hiramatsu, Y.; Kudo, T. 
Functioning of the Porcine Pituitary-Adreno- 274 cortical Axis during Neonatal Development Klemcke, H.G.; Brown-Borg, H.M.; Borg, K.E.

Ontogeny of Dopamine Daily Rhythms within 287

Rabbit Brainstem Regions

Gingras, J.L.; Lawson, E.E.; McNamara, M.C.

Main Routes of Plasma Lactate Carbon Disposal 295 in the Midgestation Fetal Lamb Carter, B.S.; Moores, R.R., Jr.; Teng, C; Meschia, G; Battaglia, F.C.

Abstracts

Abstracts of the 6th European Workshop on 301

Neonatology

Moscow, Russia, July 6-9, 1995

Author Index, Abstracts of the 6th European 316

Workshop

No. 5

Original Paper

Endothelin 1-21 Plasma Concentrations on Days 317

1 and 4 of Life in Healthy and Ill Preterm Neo-

nates

Malamitsi-Puchner, A.; Economou, E.; Efstathopoulos, T.;

Sevastiadou, S.; Hadzistamatiou, Z.; Nicolopoulos, D.

Profile of Alveolar Gases during Periodic and 322 Regular Breathing in Preterm Infants Pereira, M.R.; Reis, F.C; Landriault, L.; Cates, D.B.; Rigatto, H.

Iron Saturation Alters the Effect of Lactoferrin 330 on the Proliferation and Differentiation of Human Enterocytes (Caco-2 Cells) Oguchi, S.; Walker, W.A.; Sanderson, I.R.

A Portable Device for Estimating the Rate of $\quad 340$

CO2 Production in Preterm Infants Kien, C.L.; Murray, R.D.; Knerr, T.L.; McClead, R.E.;

Cordero, L., Jr.

Renal Blood Flow Velocity in Non-Distressed 346 Preterm Infants during the First 72 Hours of Life van de Bor, $M$.

Effects of Epinephrine on the Cardiorespiratory 352 Response to Hypoxia in Sedated Newborn Piglets with Intact and Denervated Carotid Bodies Suguihara, C; Hehre, D.; Bancalari, E.

Effects of Yersinia enterocolitica Infection on $\quad 360$

Growth of the Body and Internal Organs in Newborn Colostrum-Deprived Piglets Shu, D.;

Simpson, H.V.; Xu, R.-J.; Mellor, D.J.; Reynolds, G.W.; Marshall, R.B.

Developmental Factors in the Contractile 370

Response of Rabbit Urinary Bladder: Effect of Anoxia and Extracellular Acidosis Yoon, J.-Y.;

Zderic, S.A.; Duckett, J.W.; Snyder, H.M. Ill; Levin, R.M.

Examination for Toxicity of a Chinese Drug, the 376 Toad Glandular Secretory Product Chan

$\mathrm{Su}$, in Pregnant Mice and Embryos Chan, W.Y.; Ng, T.B.; Yeung, H.W.

Short Communication

Changes in Serum Lipid, Lipoprotein and Corti- 381

costerone Concentrations during Neonatal Chick

Development

Latour, M.A.; Peebles, E.D.; Boyle, C.R.; Brake, J.D.;

Kellogg, T.F.

$\mathrm{V}$ 
No. 6

Review

Cooperation between Transcription Factors 387

Regulates Liver Development Aran, A.; Cassuto, H.; Reshef, L.

Original Paper

Responsiveness to the Odour of Amniotic Fluid 397

in the Human Neonate

Schaal, B.; Marlier, L.; Soussignan, R.

Monoamine Neurotransmitters and Metabolites 407

in the Cerebrospinal Fluid following Perinatal

Asphyxia

Blennow, M.; Zeman, J.; Dahlin, I.; Lagercrantz, H.

Influence of Early Feeding Mode on Body Com- 414

position of Infants

Butte, N.F.; Wong, W.W.; Fiorotto, M.;

O’Brian Smith, E.; Garza, C.

Effect of Nordihydroguaiaretic Acid on Cerebral 425 Blood Flow and Metabolism during Hypoxia in Newborn Piglets

Goplerud, J.M.; McGowan, J.E.; Marro, P.J.; Delivoria-Papadopoulos, M.

Ethanol, Morphine and Barbiturate Alter the 432

Hemodynamic and Cerebral Response to

Cocaine in Newborn Pigs

Albuquerque, M.L.C.; Kurth, CD.; Monitto, C.L.;

Shaw, L.; Anday, E.K.

Signaling Pathways Regulating Ornithine Decar- 441 boxylase Activity in the Embryonic Chicken Shibley, LA., Jr.; Pennington, S.N.

Short Communication

Failure of Immunoglobulins to Prevent Neonatal 450 Thrombocytopenia in Mothers with Immuno-thrombocytopenic Purpura Zuppa, A.A.; Tornesello, A.; Mastrangelo, R.

Author Index Vol. 67, 1995453

Subject Index Vol. 67, 1995455

Suppl. 1

10 Years of Research on Porcine Derived Lung Surfactant

Proceedings of the 10th International Workshop on Surfactant Replacement Versailles, France, May 14-16, 1995

VI

Contents 